Abstract

\title{
Potential Effects of Liquidambar orientalis Mill. Against HT-29 and HCT-116 Cell Lines ${ }^{\dagger}$
}

\author{
Sumeyra Cetinkaya, Ilknur Cinar * and H. Gul Dursun \\ Medical Biology Department, Meram Medical Faculty, Necmettin Erbakan University, Konya 42090, Turkey; \\ cetinkayasumeyra0@gmail.com (S.C.); ilknurcinar@msn.com (H.G.D.) \\ * Correspondence: ilknurcinar@msn.com \\ + Presented at the 2nd International Conference on Natural Products for Cancer Prevention and Therapy, \\ Kayseri, Turkey, 8-11 November 2017.
}

Published: 10 November 2017

\begin{abstract}
Medicinal plants are natural sources which contain a wide range of substances. They are often used to treat various diseases due to their antimicrobial, antimutagenic and antioxidant effects. Also they are best source of many drugs. Liquidambar orientalis Mill. (L. orientalis), a medical plant is an endemic tree species in the Mediterranean region. L. orientalis also called as sweet gum, is used for such as some skin, respiratory and gastric ulser disease. We prepared 3 extracts each of fruid, leaf and storax by use different polarity solutions. For all extracts are studied cytotoxicity assay by XTT methods in colorectal cancer cell line (HT-29, HCT-116). The most cytotoxic extract is chosen to quantitative real-time PCR (qRT-PCR) analysis. To gene expression, total RNA isolated from both cell lines and NF-kB Signaling Pathway PCR Array ( 88 gene and 8 housekeeping gene) was studied. Leaf methanol extracts estimated IC50 values of respectively $28.30 \mathrm{uM}, 40.42 \mathrm{uM}$ in HT-29, HCT116 cell lines after treatment with different doses of extract for $48 \mathrm{~h}$. According to our results some significant inflammation and immune response genes expression seem to be change (such as IL1B, TNFRSF10A). L. orientalis extract may strong potent cytotoxic and anti-inflammatuar agent for colorectal cancer.
\end{abstract}

Keywords: L. orientalis; colorectal cancer; inflammation; NF-kB

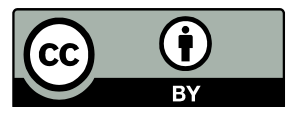

(C) 2017 by the authors. Licensee MDPI, Basel, Switzerland. This article is an open access article distributed under the terms and conditions of the Creative Commons Attribution (CC BY) license (http://creativecommons.org/licenses/by/4.0/). 